\title{
PERAN SAHABAT DALAM MEREKOSTRUKSI KEBERADAAN HADIS NABI MUHAMMAD SAW
}

\author{
Kaharuddin dan Syafruddin \\ Institut Agama Islam (IAI) Muhmammadiyah Bima \\ Kaharazzam@gmail.com
}

\begin{abstract}
Abstrak
Hadis termasuk rangkaian sejarah kehidupan Nabi Muhammad SAW, sahabat, dan masyarakat sekitarnya. Fakta historis ini pun harus dipahami, karena kedudukan hadis dalam doktrin skriptual Islam merupakan pedoman yang kedua dari Al-Qur'an dalam kehidupan masyarakat, sahabat sekitarnya maupun masyarakat yang hidup sampai hari ini. Meskipun hasus diketahui bahwa dalam sejarah perkembangan hadis di antara para ulama masih terjadi perbedaan dalam menyusun periodesasi perkembangan hadis. Tetapi banyak yang menguraikannya menjadi periodesasi, seperti masa Rasulullah, sahabat, tabi'in, masa pentadwinan atau pembukaan, masa seleksi atau penyaringan hadis serta masa sesudahnya. Dari beberapa periodesasi itu menunjukkan bahwa keberadaan hadis tidak terlepas dari peranan masyarakat sekitar Nabi, khususnya para sahabat. Peran para sahabat dalam membentuk hadis sangat vital dikerenakan mereka adalah subyek sekaligus objek sejarah secara langsung yang mempengaruhi pembentukan dan keberadaan hadis Nabi Muhammad SAW.
\end{abstract}

Kata Kunci : Masyarakat, Nabi, hadis, dan Sahabat.

\section{Pendahuluan}

unnah (Hadis) menurut bahasa berarti "kebiasaan dan jalan (cara) yang baik dan yang jelek" atau "jalan (yang dilalui), baik yang terpuji maupun yang tercela atau jalan yang lurus atau tuntutan yang tetap (konsisten). "apabila kata sunnah behubungan dengan hukum syara', yang dimaksudkan adalah segalah sesuatu yang dipperintahkan, dilarang atau dianjurkan oleh RasulullahSAW, baik berupa perkataan maupun perbuatan. Dengan demikian, apabila dalam dalil hukum syar'disebutkan dalam al-kitab dan as-Sunnah, yang dimakksudkan adalah Al-Qur'an dan Al-Hadis. Menurut ahli Ushul, sunnah adalah " segala sesuatu yang bersumber dari Nabi Muhammad SAW. Berupa perkataan, perbuatan, baik sebelum menjadi Rasul maupun sesuadanya" atau "segalah sesuatu yang berhubungan dengan sirah (perjalanan hidup) Nabi SAW, budi pekerti, perkataan, dan perbuatanya, baik melahirkan syara' maupun tidak". ${ }^{2}$

Hadis termasuk sumber kedua dalam Islam setelah al-Qur'an. Pada masa Rasulullah, hadis melekat dalam memori para sahabat dan belum banyak ditulis, bahkan di awal-awal wahyu, hadis dilarang untuk dicatat karena khawatir bercampur dengan al-Qur'an. Para sahabat merupakan penyambung lidah Rasulullah. Banyak diantara mereka yang mendengar berbagai hal secara langsung dari Rasulullah. Bahkan Umar bin Khattab secara bergantian dengan tetangganya menghadiri majlis Nabi SAW. Namun banyak diantara sahabat yang tidak menulisnya karena disamping ada larangan, alat-alat pendukung tulis menulis pada saat itu masih

${ }^{1}$ Mustofa Hasan, Ilmu Hadis (Bandung: Pustaka Setia,2012), 19 
belum banyak, dan yang paling utama adalah bahwa pada umumnya masyarakat masih belum melek tulisan serta kuatnya tradisi hafalan mereka. ${ }^{2}$ Sehubungan dengan hal tersebut, dalam catatan sejarah perkembangan hadis Nabi Muhammad SAW, dari deretan sahabat serta orang terdekat yang sangat berperan dalam merekonstruksi kebedaaan hadis Nabi, Aishah termasuk bagian dari contoh tokoh intelektual yang sangat penting dalam sejarah Islam. Kecemerlangannya meliputi banyak sekali bidang ilmu pengetahuan. Aishah adalah seorang pakar di bidang tafsir, tauhid, akidah, fiqih, sejarah, genealogi, syair Arab, bahkan termasuk hal yang berkaitan dengan periwayatan hadis-hadis Nabi. Ia menjadi rujukan orang-orang yang hidup di masanya. Ibnu Syihab al-Zuhri pernah berkata, "Jika ilmu seluruh manusia, termasuk ilmu para istri Rasulullah SAW. dibandingkan, maka ilmu Aishahlah yang paling luas."3

Meskipun dalam konteks perkembangan hadis Nabi SAW, dikalangan ulama terdapat perbedaan pendapat. Ada ulama yang mengartikan sunah sama dengan hadis, ada pula ulama yang membedakannya, bahkan ada ada yang memberi syarat-syarat tertentu, yang berbeda dengan istilah hadis. Ulama ushul fiqh memandang Nabi sebagai undangundang yang hidup, oleh karena itu, sunnah diartikan sebagai peraturan yang bersifat mengatur, membina, mengendalikan, mengikat, memaksa, dan memberi pelajaran. ${ }^{4}$ Adapun pengertian sunnah diungkapakan oleh Muhammad Ajaj Al-Khatib, "segalah yang dinukilkan dari Nabi SAW, baik berupa perkataan, perbuatan, taqrir, pengajaran, sifat, kelakuan, perjalanan hidup, baik sebelum Nabi diangkat jadi Rasul atau sesudahnya". 5 Para ahli hadis tidak membedakan antara hadis dan sunnah. Menurut mereka. Hadis atau sunnah adalah ha-hal yang berasal dari Nabi Muhammad SAW, baik berupa perkataan, perbuatan, penetapan maupun sifat bilau, dan sifat ini, baik berupa sifat-sifat fisik, moral maupun periflaku, sebelum biliau menjadi Nabi maupun sesudahnya.

Berdasarkan penelaahan uraian di atas, maka sesungguhnya tulisan ini ingin mengkaji peran sahabat dalam merekonstruksi keberadaan hadis nabi Muhammad SAW., yang mencakup beberapa hal diantaranya; gambaran kondisi masyarakat Mekkah dan Madinah pada masa perkembngan Islam, peran sahabat dalam pembentukan hadis, termasuk upaya para sahabat dalam penyelematan keberadaan hadis Nabi Muhamma SAW.

\section{Masyarakat Mekkah dan Hadis yang Terbentuk pada Masa awal Perkembangan Islam}

Masa awal Islam di Mekkah bisa dikatakan sebagai masa pembangunan pondasi dasar atau pijakan dasar dari perkembangan Islam. Kondisi Mekkah sejak awal sebelum

${ }^{2}$ Lihat Saifuddin Zuhri Qudsy, "Umar bin AbdulAzis dan Semangat penulisan Hadis", Jurnal Esensia Vol. XIV No. 2 Oktober 2013, 258-259.

${ }^{3}$ Lihat Umniyatul Istiqlaliyah, "Peran dan Pengaruh Aishah dalam Bidang Hadis", Jurnal Dirosat: Journal For Islamic Studies Vol. 1 No. 1 Januari 2016, 42-43.

${ }^{4}$ Mustofa Hasan, 20.

${ }^{5}$ M. Agus Solahudin \& Agus Suyadi, Ulumul Hadis (Bandung : Pustaka Setia, 2009), 11. 
Islam merupakan tempat perdagangan yang sangat pesat dengan ciri umum penduduk Mekkah dan kebiasaannya berdagang keluar Mekkah. Ini semua menjadi bekal buat kita untuk memahami konteks sosireligius pada dakwah Islam fase Mekkah. Dakwah Nabi SAW pada masyarakat Mekkah ini berpengaruh pada turunnya ayat-ayat Al-Qur'an dan munculnya chadis sebagai pedoman Islam. Situasi menjelaskaan bahwa pada saat seperti itu hadis lahir berupa sabda (aqwal), af'al dan taqrir Nabi yang berfungsi menerangkan Al-Qur'an dalam rangka menegakkan syari'at Islam dalam pembentukan masyarakat Islam.

Mengingat pentingnya sebuah suku dalam komunitas Mekkah, maka Nabi diperintahkan untuk mula-mula menyebarkan Islam dikalangan kerabatnya seperti besarnya pengaruh suku Quraisy dikalangan penduduk Mekkah yang kerenanya bisa dibayangkan betapa terpukulnya Muhammad SAW ketika ia mengumpulkan keluarganya dalam suatu jamuan yang santai dan mengajak mereka kke jalan Allah, namun ternyata keluarganya menolak dan hanya Ali Bin Abi Thalib yang berani dan mau menjadi pembantunya. Puluhan orang yanng hadir mentertawakan Muhammad dan Ali. Tidak seorangpun menyadari bahwa beberapa diantara undaangan ini akan ditebas oleh Ali di medan Badar, empat belas tahun kemudian, zsebagai bukti kesungguhan Ali.

Besarnya pengaruh suku Quraisy di Mekkah jugalah yang salah satunya bisa membuat hamzah memeluk Islam, ketika Abu Jahl dari bani Hamzahlah mencaci dan mengejek Muhammad, lalu orang -dorang melapor pada Hamzah dan serta merta Hamzah-lah yang menghajar kepala Abu Jahl dengan busur panahnya. Icnseden ini berbuntut panjang kalau saja spirit suku pada saat itu tidak segera padam. Ketika Abu Thalib masih hidup, bani Hasyim memberi perlindungan pada Muhammad dan tidak ada yang berani karena baninya akan membalasnya nanti. Ketikah Islam hadir di Mekkah dapatlah kita baca beberapa literatur bahwa fase Mekkah bercirikan ajaran Tauhid. Tetapi sesungguhnya bukan haanyaa persoalan teologis semata, juga seruan Islam akan keadilan sosial, seperti perhatian pada anak yaatim, fakir miskin, dan pembebasan budakserta ajaran Islam akan persamaan derrajat manusia, yang menimbulkan penolakan keras pendudukan Mekkah pada Muhammaad, bagi mereka, agama ini tidak hanya "merusak" idiologi dan teologi meereka, tetapi juga " merombak" kehidupan sosial mereka. Hadis yang lahir pada masa seperti ini misalnya: "saudara-saudaramu adalah pembantumu yang telah dijadikan Allah milik dibawah tanganmu. Maka siapa yang saudaranya dibawaah tanggung jawabnya, hendaknya diberi makanan dari makananya daan diberi pakaian dan tidak membebaninya. Barang siapa yang membebaninya dengan beban yang memberatkannya maka hendaknya dia menolongnya.

Rasulullah bermaksud dengan sabdanya ini mengingatkan umatnya agar tidak semena-mena terhadap orang yang berada dibawahnya sebab manusia itu bersaudara. Bahwa semua berasal dari Nabi Adam, dan Nabi Adam berasal dari tanah. Maka jika bersaudara dalam agama, justru mmereka harus saling menguatkan. Contoh menarik, misalnya, dalam Al-Qur'an dijelaskan tentang kata " Karim” dalam masyarakat Jahiliyyah merupakan bagian penting kode etik mur'ah cita-cita moral tertinggi mmasyarakat arab jaahiliyyah yang mencakup antara lain, kejujuran, keberanian, 
kesetiaan, dan kedermawanan serta keramah-tamahan. Keberanian kedigiayaan teutama didtunjukkan pada saat pertempuran dan penyamunan. Loyalitas terfokus pada ikatanikatan kesukuan dan perjanjian. Kedermawanan dan fkeramah-tamahan terutama ditunjukkan dalam menjamu tamu, dan seringkali dengan maksud meninggikkan status seseorang dihadapan tetamunya.

Konsep "Karim" diatas mengalami perubahan makna yang drastis ketika Al-Qur'an dengan tegas mengatakan bahwa manusia yang paling mulya (akram) dalam pandangan Allah ialah yang paling bertaqwa kepada-Nya. Bagi yang tidak mengetahui konteks di atas, pernyataan Al-Qur'an itu akan terdengar biasa saja. Tapi bagi orang-orang pada masa Muhammad, pernyataan di atas betul-betul radikal. Jika konteks arab jahiliyyah berikut kedudukan kata karim dalam pandangan dunia mereka dipahami, maka yang terjadi adalah revolusi cita-cita moral arab. Bukan orang yang berharta banyak, menang dalam pertempuran dan seorang bbangsawan yang disebut karim, tapi mereka yang bertqwa, implikasinya budak hitam legam pun dapat di pandang karim.radikalisasi makna pandangan dunia (weltancshaung) arab jahiliyyah yang dilakukan Islam seperti inilah yang sedikit banyak menggoncang penduduk Mekkah.

Berdasarkan urian tersebut, dapatlah diambil kesimpulan secara tentatif bahwa masyarakat Islam pada kurun Mekkah belum lagi tercipta sebagai sebuah komunitas yang mandiri daan bebas dari curusan bani. Negara Islam juga belum terbentuk pada dakwah dalam titik tertentu terjadi radikalisasi makna dalam pandanngan arab jahilidyyah yang beripplikasi mengguncang tataran sosioreligius penduduk Mekkah.

\section{Masyarakat Madinah dan Hadis yang Terbentuk pada Masa Lanjutan Perkembangan Islam}

Perkembangan Islam pada masa madinah setelah Nabi Muhammad SAW hijrah dapat dikatakan sebagai masa penyempurnaan agama islam. Hijrah ke madinah tidaklah terwujud begitu saja. Ada beberapa pra kondisi seperti baiat aqobah (pertama dan kedua). Kedua baiat ini merupakan batu-batu pertama bagi bangunan negara Islam. Kehadiran rasulullah saw melalui peristiwa hijrah ke dalam masyarakat madinah yang majemuk amat menarik untuk di bahas. Peta demografis madinah saat itu adalah sebagai berikut;

a. Kaum muslimin yang terdiri dari muhajirin dan anshar

b. Mawali dan hamba-hamba sahaya

c. Anggota Aus dan Khajraj yang masih menganut paganism

d. Orang-orang yahudi yang terbagi dalam tiga suku utama: Bani Qoinuqo, Bani Nadhir Quraidhoh. ${ }^{6}$

Kemajemukan komunitas tersebut melahirkan konflik dan tension. Pertentangan suku Aus dan Khazraj sudah terlalu terkenal dalam sejarah Islam. Bahkan diduga diterimanya Rasul di Madinah (Yatsrib) dengan baik di kedua Bani tersebutmembutuhkan " orang ketiga" dalam konflik diatara mereka. Hal ini dipahami dalam manajemen

${ }^{6}$ Abdul Aziz, Abdullah, Mujtama al-Madinah fi 'Ahd ar-Rosul (Riadl. Jami'ah Al-Malik Su'ud. 1982), 31-30. 
konflik politik. Adapun diterimanya Rasul oleh kaum Yahudi merupakan cataatan tersendiri. Tentu saja Yahudi menerima Nabi dengan

kecurigaan tetapi pendekatan yang dilakukan Nabi mampu "menjinakkan" mereka, paling tidak, sampai Nabi eksis di Madinah.

Kemajemukan komunitas Madinah membuat Rasul melakukan negosiasi dan konsolidasi melalui perjanjian tertulis yang terkenal dengan " Piagamm Madinah". Piagam Madinnah sesungguhnya merupakan rangkaian penting dari proses berdirinya negarah Madinah, meskipun Nabi selaku " mandataris" piagam Madinah tidak pernah mengumumkan bahwa biliau mendirikan negara, dan tidak satupun ayat Al-Qur'an yang memmerintahkan beliau untuk membentuk suatu negara. Dari sudut pandang ilmu politik, obyek yang dipimpin oleh Nabi SAW. Memenuhi syarat untuk disebut berbagai negara. Syarat berdirinya negara ialah ada wilayah, penduduk dan pemerintahan yang berdaulat.kenyataan sejarah menunjukkan adanya elemen negara tersebut. Wahhasil, setelah melalui proses Bai'at daan Piagam Madinah Nabi dipandang bukan saja sebagai pemimpin rohani tetapi juga sebagai kepala negara.

Persoalan ajaran Islam, pada fase Madinah ini ajaran Islam merupakan kelanjutan dari dakwah fase Mekkah.bila pada fase Mekkah, ayat tentang hukum belum banyak dditurunkan, maka pada fase Madinah kita mendapati ayat hukum mulai turun ayat melengkapi ayat yang telah ada sebelumnya. Ini bisa dipahami mengingat hukum bisa dilaksanakan bila komunitas telah dibentuk. Juga dapat dicatat kemajemukan komunitas Madinah turut mempengaruhi ayat hukum ini. Satu contoh menarik pada peristiwa kewajiban zakat dan pelarangan riba. Setting sosial ekonomi Madinah yang dikuasai oleh Yahudi memerlukan sebuah "perlawanan" dalam bentuk zakat (untuk pemerataan ekonomi di kalangan muslim) dan pelarangan riba. Yang terakhir ini membawa implikasi baik secara ekonomi maupun politik bagi praktek riba kaum Yahudi. Selain masalah ayat hukum saja yang berangsur-angsur " sempurna", juga ayat tentang etika, tauhid dan seluruh elemen ajaran Islam berangsur-angsur mendekati titk kesempurnaan, dan mencapaai puncaknya, setelah Nabi Wafat, didmulailah era khulafah al-Rasyidin, tidak dapat dipungkiri, di Madinah Islam sempurnah dan disinilah awal sebuah peradaban yang dibaangun oleh umat Islam mulai tercipta.

\section{Peran Sahabat Dalam Merekonstruksi Pembentukan Hadis Muhammad SAW}

Kehidupan Rasulullah SAW., dalam rutinitasnya berada ditengah-tengah masyarakat serta dikelilingi oleh sahabatnya. Merekaa dapat bertemu dan bergaul bebas dengan Rasulullah tanpa ada aturan dan protokoler yang dapat menghalangi para sahabat untuk bertemu. Nabi bergaul dengan mereka di rumah, cdi masjid, di pasar, di jalan, di dalam safar dan di dalam hadhar. Seluruh perbuatan, ucapan dan tuturkata pada saat itu menjadi perhatian yang sangat penting bagi sahabat. Segala gerak gerik Nabi mereka jadikan pedoman hidup merekapun tidak terhalang oleh jarak maupun waktu, semua itu menunjukkan kesungguhan para sahabat dalam meneladani Rasul. Seluruh hal ihwal Nabi 
pun mereka rekam dalam memori mereka dan sebagian dari mereka mengabbdikan haddis-hadis Nabi melalui tulisan. ${ }^{7}$

Meskipun, pada perkembangannya diantara para ulama masih terjadi perbedaan dalam menyusun periodesasi pertumbuhan dan perkembangan hadis. Tetapi banyak pula yang menguraikannya menjadi periodesasi, seperti masa Rasul SAW, sahabat, tabi'in, masa pentadwinan atau pembukaan, masa seleksi atau penyaringan hadis serta masa sesudahnya. Dari beberapa periodesasi itu menunjukkan bahwa keberadaan hadis tidak bisa lepas dari peran masyarakat sekitar Nabi, khususnya para sahabat. Peran para sahabat dalam membentuk hadis sangat vital di kerenakan mereka adalah subyek sekaligus objek sejarah pada waktu itu. Sehubungan dengan hal tersebut, terdapat beberapa beberapa pengaruh sahabat dalam proses terbentuknya hadis di antaranya :

1. Karena pertanyaan sahabat tentang hal yang mereka tidak ketahui.

Seringkali hadis lahir karena sahabat mengajukan pertanyaan pada Nabi SAW. Misalnya hadis yang diriwayatkan oleh at-Thurmudhidalam sunnah at-Thurmudhi dari Abi Amamah tentang mengucapkan salam. Diriwayatkan oleh Abi Imamah bahwa dia telah berkata kepada Rasulullah: "Ya, Rasulullah kami telah saling berjumpa, siapa diantara kami yang harus lebih dahulu mengucapkan salam ?. Sabda Rasulullah.

Artinya: Menceritakan pada kita Ali Ibn Hajar menggambarkan kepada kita Qiran Ibn Tamam al-Asadi dari Abi Furah Yazid Bin Sunan dari Salim bin'amr dari Abi Amam bertanya pada Rasulullah: wahai Rasulullah jika dua orang laki-laki sedang bertemu dan siapa lebih dahulu mengucapkan salam, maka Rasulullah menjawab yang lebih dahulu.

2. Karena situasi dan kondisi yang terjadi di masyarakat.

Rasulullah SAW berbicara kepada orang sesuai dengan kadar intelektual mereka, suatu pembicaraan yang tidak dapat dipersepsi oleh akal, pendengaran, justru akan menimbulkan kesalahpahaman. Sehingga yang terjadi tidak seperti dikehendaki. Rasulullah benar-benar berbicara kepada mereka yang hadir dengan bahasa yang dapat mereka tangkap pengertiannya. Sehingga orang pedalaman, dengan kekerasan karakternya mampu memahami. Demikian pula orang kota, dapat memahaminya sesuai dengan pola hidup daan kondisi lingkungannya.

Rasulullah SAW., dalam menyampaikan hadis benar-benar memperhatikan situasi dan kondisi yang ada, sehingga apa yang disampaikan biisa ditangkap pengertianya, oleh karena itu penyampain hadis Nabi SAW memperhatikan siapa yang diajak berbicara, perbedaan daya tangkap, kecerdasan dan kemampuan alami maupun hasil latihan mereka dalam berfikir, salah satu buktinya adalah hadis diriwayat Abu Hurairah: Artinya: menceritakan pada saya Asbagh bin al-Farj dari Ibn Wahab dari Yunus dari ibn Shihab dari aabi Salamah bin abd al-Rahman dari abu Hurairah : Sesunguhnya seseorang lakilaki arab datang pada Rasulullah dan ia bertanya, "sesungguhnya istriku telah melahirkan anak yang berkulit hitam, dan aku tidak mengakuinya. "lalu Nabi bertanya kepadanya: 1995), h. 45

${ }^{7}$ Al-Jazairy, Thohir, Taujih An-Nadzor Ila Ushul Al-Atsar, (Maktabah al-Mathu'at al- Islamiyyah. 
"apakah kamu mempunyai unta?" ia menjawab: "ya." Beliau bertanya ; “ apa warna kulitnya ?" ia menjawab: "merah." Beliau bertanya: "apakah diantara unta itu ada yang warna keabua-abuan.” Beliau bertanya lagi : "bagaimana bisa begitu?" ia menjawab: “ mungkindi pengaruhi oleh faktor keturunan." Beliau bersabda : "nah, anakmu itu juga barangkali dipengaruhi oleh faktor keturunan, dan Nabi meremehkan atas pengingkarannya.

Menurut analisa penulus, dialog ini jelas merupakan cara Rasul untuk menundukkan orang tersebut agar mengakui anak yang telah diingkarinya, dengan menganalogikannya dengan peristiwa yang terjadi, baik berkenan dengan kehidupan sehari-hari maupun kondisi lingkungannya. Selain ditujukan kepada akal, pembicaraan Rasulullah SAW., juga ditujukan kepada rasa dan nurani. Sehingga arah pembicraannya mampu menggerakkan perasaan dan iman dari segala ketidaktahuan yang berkenaan dengan hukum dasar kehidupan. Kondisi inilah yang menjadi dasar sehingga para sahabat pada massa itu, memposisikan segala perkataan, perbuatan, dan takrir yang ditunjukan Nabi Muhammad SAW sebagai sandaran hukum dalam kehidupan sehari-hari, serta harus diwariskan pada seluruh pengikut ajaran Islam.

\section{Upaya Para Sahabat Dalam Penyelamatan Keberadaan Hadis Muhammad SAW}

Perkembangan hadis Nabi, dalam sejrahnya pernah- dihadapkan dengan persoalan gencarnya bermunculan hadis palsu di tengah-tengah kehidupan masyarakat. Di dasari hal tersebut, untuk menyelamat hadis Nabi Muhammad SAW, para ulama, tabi'in dan sahabat menuyusun berbagi kaidah penelitian hadis. Adapun langkah-langkah yang ditempuh oleh para sahabat sebagai berikut:

1) Meneliti sistem penyandaran hadis. Para sahabat dan tabiin tidak sembarang tidak sembarangan mengambil hadis dari seseorang.mereka meneliti dengan seksama proses penukilan dan periwayatan hadis. Meskipun pada masa sahabat hamipr tidak ada penyelewengan dalam periwayatan hadis, sehingga ketika mereka mendaptakan dari sahabat lain mereka tidak akan menanyakan hadis itu didapat. Tapi semenjak terjadinya fitnah al-kubra mereka menyeleksi hadis-hadis yang di dapat dari orang lain. ${ }^{8}$

2) Memilih perawi perawi hadi yang terpercaya. Para ulama menanyakan hadishadis yang dipandang kabur atau tidak jelas asal-usul kepada para sahabat, tabi'in dan pihak menekuni bidang ini. Mereka tidak sembarang untuk meriwayatkan hadis. Mereka akan memilih dari orang tertentu yang dipandang menguasai dan mengethuai persoalan ini. ${ }^{9}$

3) Studi kritik rawi,yang nampaknya lebih konsetrasi pada sifat kejujuran dan kebohongan. Oleh karena itu, mereka tidak akan mengambil dari orang-orang yang suka berbohong baik dalamkehidupan umumnya; suka berbuat bida'ah

${ }^{8}$ Lihat Munzeir Suparta, Ilmu Hadis (Cet. VIII; Jakarta: PT Rajawali Grafindo, 2013), 192.

${ }^{9}$ Ibib. 
dan mengikutihawa nafsunya; orang-orang fasik,zindiq,dan orang yang tidak menguasai apa yang disampaikannya. ${ }^{10}$

4) Menyusun kaidah untuk meneliti hadis-hadis tersebut.misalnya saja dengan mengetahui batasan-batasan hadis shahih, hasan, dan dha'if. ${ }^{11}$

Berdasarkan berbagai kaidah dan ilmu hadis,disamping telah dibukuknnya hadis,mengakibatkan ruang gerak para pembuat hadis palsu menjadi sempit. Selain itu, hadis-hadis yang berkembang di masyarakat dan termasktub dalam kita-kitab yang dapat diteliti dan dkethu kualitasnya.dengan menggunakan berbagiai kaidah dan ilmu hadei itu, para ulama telah berhasil menghimpun berbagai hadis palsu dalam kitab-kitab khusus. seperti; Al-Mudhu'Al Kubra karangan Abu Al-Fari 'Abd Al-Rahman bin Al Jauzi (508$597 \mathrm{H}$ ) dalam empat jilid; Al-Ba'its 'ala Al-Khalas min Hawadist Al-Qishas,oleh Hafidz Zain Al-Din 'Abd Al- Rahman Al-Araqi (725-806 H); Tanzil Al Sya'ah Al-Mafu'ah min Al-Ahbar Al-Syam 'aiti Al-Maudhu'at oleh Abu Al-Hasan 'Ali bin Muhammad AlKanany (w. 936 H); Al-Qawaid Al-Majmu'ah fi Hadist Al-Maudhu'at oleh Qadhi Abu Abdullah Muhammad bi Ali as-Syanhani (1173-1255 H) ${ }^{12}$.

\section{Penutup}

Hadis (sunnah) yang lahir pada saat Nabi Muhammad SAW tidak dapat terlepas dari kondisi dan situasi mmasyarakat dimana hadis itu terbentuk, sserta tidak lepas dari peran sahabat pada masa itu. Masyarakat dan sahabat merupakan subjek sekaligus objek dari terbentuknya hadis. Dhadis hadir mengiringi dan menjelaskan ayat-ayat Al-Qur'an, sekaligus sebagai jawaban-jawaban kejadian-kejadian ataau kasus yang terjadi baik mmasalah ibadah maupun muamalah. Mengingat pentingnya kedua faktorpembentuk lahirnya hadis, yaitu kondisi masyarakat dan peran sahabat, maka untuk mempelajari hadis pada saat initida bisa mempelajari hadis berdasarkan teksnya belaka (tekstual), tetapi perlu juga pelajari konteks saat hadis itu lahir. Berdasarkan uraian pembahasan diatas, jelaslah mempelajari hadis perlu mengkaji historis, sosiologis dan antropologis (kontekstual masyarakat pada saat dimana hadis itu lahir).

\section{Daftar Pustaka}

Abdul Aziz, Abdullah. Mujtama al-Madinah fi 'Ahd ar-Rosul. Riadl. Jami'ah Al-Malik Su'ud. 1982.

Agus Solahudin \& Agus Suyadi, Ulumul Hadis. Bandung : Pustaka Setia, 2009.

Al-Jazairy, Thohir. Taujih An-Nadzor Ila Ushul Al-Atsar. Maktabah al-Mathu'at alIslamiyyah. 1995.

Ash Shiddieqy, Teungku Muhammad Hasbi. Sejarah dan Pengantar Ilmu Hadits. Cet.IV, Semarang: PT. Pustaka Rizki Putra, 1999.
${ }^{10} \mathrm{Ibib}$.
${ }^{11} \mathrm{Ibib}$.
${ }^{12}$ Ibid., 193. 
Istiqlaliyah, Umniyatul. "Peran dan Pengaruh Aishah dalam Bidang Hadis", Jurnal Dirosat: Journal For Islamic Studies Vol. 1 No. 1 Januari 2016.

Mustofa Hasan, Ilmu Hadis. Bandung: Pustaka Setia, 2012.

Qudsy, Saifuddin Zuhri. "Umar bin AbdulAzis dan Semangat penulisan Hadis", Jurnal Esensia Vol. XIV No. 2 Oktober 2013.

Suparta, Munzeir. Ilmu Hadis. Cet. VIII; Jakarta: PT Rajawali Grafindo, 2013. 